\title{
The effect of race on CEO pay-performance sensitivity in South Africa
}

\author{
by Mark Bussin ${ }^{\star}$ and Sean Barrett
}

\begin{abstract}
South Africa's labour policies and the growing societal calls to better explain executive remuneration create a unique opportunity to examine the effects of race on CEO pay. This empirical research study sought to investigate the effects of race on the sensitivity of executive pay to corporate performance. The study aims to contribute to the literature by providing an evidence-based approach to understanding the effect of race on CEO remuneration. The research design was quantitative, descriptive and longitudinal in nature, utilising validated secondary data sources. The sample consisted of 19 black CEOs and a random sample of 45 white CEOs. All components of South African CEO remuneration studied were found to correlate strongly with PAT (Profit after Tax) and EBITDA (Earnings before Interest, Taxes, Depreciation and Amortisation) and to a lesser degree with ROE (Return on Equity) and HEPS (Headline Earnings per Share). Black and white CEO mean remuneration was found to show no significant difference as a result of race. A notable difference found was the higher degree of payperformance sensitivity and variability seen within the black CEO sample. The study showed that race does not affect the level of CEO remuneration but does impact on pay-performance sensitivity and variability.
\end{abstract}

Key words: remuneration, compensation, race, minority CEO remuneration, payperformance sensitivities, South Africa

\section{Introduction}

\subsection{Key focus of the study}

South Africa's labour policies and growing societal calls to better explain executive remuneration create a unique opportunity to examine the effect of race on CEO pay. Past research has revealed a polarised picture regarding the effect of race on CEO remuneration (Bussin \& Modau 2015). This division centres on whether race has a positive impact on the level and sensitivity of remuneration received.

\subsection{Background to the study}

South Africa has one of the highest levels of income inequality in the world (Tregenna \& Tsela 2012) combined with an official unemployment rate of greater than $25 \%$ (Lehohla 2014). South Africa's 2012 tax statistics show that only $12.8 \%$ of households earned an

\footnotetext{
Prof Mark Bussin is a Professor in the Department of Industrial Psychology and People Management at the University of Johannesburg.

* Mr Sean Barrett was a student at the Gordon Institute of Business Science at the University of Pretoria
} 
income of over R400 000 per annum and the lowest quintile survived on less than R4 543 per annum. Executive remuneration continues to evoke strong reactions as CEO packages, bonuses and share options are contrasted with pervasive poverty and inequality (Bussin \& Nel 2015). Shareholder activists are becoming more vocal in their calls for reform in the ways boards remunerate executives and consider shareholder preferences (Whitfield 2013). Bussin (2013) argues, however, that context is key and despite the vast and visible inequality gap, attracting, motivating and remunerating topperforming executives will ultimately grow the economy. Wessel (2006) supports this perspective and states that CEO compensation is a result of supply and demand for the executive skills and expertise required to manage large, complex organisations.

Transformation and Black Economic Empowerment (BEE) within the C-suite have also come under fire in South Africa. Goodman-Bhyat (2013) found that black executives only accounted for $15 \%$ of executive positions while demographically black people represent $79 \%$ of South Africa's population (Lehohla 2013). Weinstock (2014) notes that this is largely in line with minority executive representation in the USA. The typical South African CEO is a white South African male in his fifties earning between R10 million and R20 million annually and having been in the position for less than five years (Goodman-Bhyat 2013). Despite the Employment Equity Act 55 of 1998 and the Broad-based Black Economic Empowerment Act 53 of 2003 black executives remain under-represented.

Research on the impact of executive minority status on remuneration is divided in its conclusions as reported in the literature. There are studies that support the view that minority status is a disadvantage and remuneration levels are adversely affected (Hill, Upadhyay \& Beekun 2014; Park \& Westphal 2013; Kulich, Trojanowski, Ryan, Alexander Haslam \& Renneboog 2011; Selody 2010). These are countered by studies that have found that the minority status of executives is in fact beneficial (McDonald \& Westphal 2013; Zweigenhaft \& Domhoff 2011; Hillman, Shropshire \& Cannella 2007; Hillman, Cannella \& Harris 2002). The majority of the above research was conducted in the USA and, as noted by Nzukuma and Bussin (2011), there is limited South African literature pertaining to black executives and remuneration.

The study of remuneration and transformation is relevant in South Africa as it provides perspective and context on how the public, media and labour drive public opinion around the topic of executive remuneration. Public opinion, in a functioning democracy, will drive future public policy and legislation and should thus not be ignored by business. The uniqueness of the South African business environment is best captured by Van Melle Kamp and Hofmeyr (2013), who quote the following statement by a prominent CEO: "corporates have a disproportionate role to play in the repositioning of the country, compared with other countries" (p. 18). This is against the backdrop of South Africa's having been rated 136 out of 144 in the 2015 Global Competitiveness Report when it comes to the relationship between pay and productivity in general.

\subsection{Trends from the research literature}

\subsubsection{CEO remuneration and corporate performance}

At the opening of the 40th World Economic Forum the former French President Nicolas Sarkozy stated that there were remuneration packages that would no longer be tolerated because they bore no relationship to merit (Gevers 2012). This quotation calls into question the relationship between CEO remuneration and corporate performance. 
Larcker and Tayan (2011) believe that at the core of the debate on CEO remuneration is the myth that executives are systematically overpaid and that pay-for-performance is non-existent. They note that the median US CEO was paid \$1 600000 in 2008 and say that this is not excessive given the responsibilities of the role. Studies in South Africa find average annual CEO remuneration to lie between R6 200000 and R7 700 000, depending on the industry (Nel 2012; Shaw 2012; Bussin 2015).

Bruce, Buck and Main (2005) disagree with Larcker and Tayan (2011) on the point that pay-for-performance is self-evident. They are quoted as saying, "one striking feature of this copious literature has been the lack of consensus regarding the relationship between corporate performance and executive pay" (Bruce et al 2005:1493). They make the argument that there is no link between CEO pay and corporate performance (Bruce et al 2005). Drawing on several other sources, they point to a statement made by Barkema and Gomez-Mejia (1998) that there has been a "failure to identify a robust relationship between top management compensation and firm performance" (p. 135).

Findings in the literature on pay-for-performance sensitivity are indeed varied. Abowd (1990), Zhou (2000), Ozkan (2011), De Wet (2013), Mobbs (2013) and many others argue that there is a positive relationship between pay and performance. On the other hand, Tosi, Werner, Katz and Gomez-Mejia (2000) found that on average firm performance only accounted for $5 \%$ of CEO pay variance. On balance it appears that there is a link between pay and performance but that this link may well be a weak one.

\subsubsection{Defining pay-for-performance measures}

In order to evaluate the relationship between pay and performance, it is first necessary to define the right set of metrics to measure both CEO remuneration and corporate performance. Remuneration has 3 main components - fixed salary, short-term incentives (STIs) and long-term incentives (LTIs). The present research covers the first two.

Two broad areas of measurement of corporate performance are defined for the purpose of this study. Accounting-based measures draw their influence from data obtained from financial reporting mechanisms. Examples include return on assets, profit after tax and the like. Market-based measures draw their influence from the economic value added by the corporation as well as the share market. Economic value includes share price growth, headline earnings per share and Earnings before Interest, Taxes, Depreciation and Amortisation (EBITDA). Essentially the market or economy based measures are removed from the accounting policies and treatments used within the business.

The following accounting-based corporate performance metrics are defined:

- "Profit after Tax" (PAT) is the profit remaining after the income tax expense has been deducted. This is reflected in the firm's statement of comprehensive income as profit for the period (Graham \& Winfield 2007).

- "Return on Equity" (ROE) is defined by Hartley, Firer and Ford (2011) as the profit attributable to shareholders in a given period expressed as a percentage of equity. As Firer, Ross, Westerfield and Jordan (2012) point out, because profit is a summation over a year, equity should be handled as average equity.

$$
R O E=\frac{\text { Net Profit After Tax }}{\left(\text { Total Equity }_{t-1}+\text { Total Equity }\right) / 2}
$$

The following economic or market-based performance metrics are defined: 
- "Headline Earnings per Share" (HEPS) is a Johannesburg Stock Exchange (JSE) requirement for listed companies and is not part of any accounting standard. It is calculated in much the same way as earnings per share except that the earnings have been adjusted to remove items of income or expense that relate to the capital base of the firm (Graham \& Winfield 2007). It therefore attempts to reflect the earnings derived from trading or operating activities.

- "Share Price" (SP) is the year-on-year change in the share price as recorded at the firm's financial year-end.

- "Earnings before Interest, Tax, Depreciation and Amortisation" (EBITDA) is found by adding back any depreciation and amortisation expenses to the published operating (or trading) profit in the statement of comprehensive income. EBITDA is seen as a reflection of operating cash flows as it excludes non-operating costs (tax and interest) and non-cash costs (depreciation and amortisation) (Graham \& Winfield 2007).

The above set of corporate performance metrics were defined for this study based on those used in previous pay-for-performance studies (De Wet 2013; Shaw 2012; Van Blerck 2012; Conyon \& He 2011; Wang \& Xiao 2011; Ghosh 2006). It was considered important to use a recognised basket of measures to assist in locating this study within the existing body of knowledge.

It was noted that the vast majority of the studies consulted state the positive effect of firm size on CEO pay (Tosi et al 2000; Zhou 2000; Baker \& Hall 1998). Given the pervasive nature of this factor, many recent studies have controlled for firm size (De Wet 2013; Cooper, Gulen \& Rau 2010). Tosi et al (2000) estimate that firm size could account for more than $40 \%$ of the variance in total CEO compensation.

\subsubsection{Minority status as a disadvantage}

It has been argued that the odds are stacked against previously disadvantaged individuals (PDIs) or - in the context of this study - black CEOs in South Africa (or ethnic minorities in the USA and European countries) in respect of both advancing to executive level and receiving similar remuneration to their white male executive colleagues (Hill et al 2014; Park \& Westphal 2013; Kulich et al 2011; Selody 2010). Kulich et al (2011) describe their minority status as an invisible barrier that prevents them from advancing up the corporate ladder, often accompanied by inequitable compensation.

McDonald and Westphal (2013) investigated the effects of mentoring on first-time minority executives and found that minority executives received comparatively less mentoring from their incumbent colleagues. This can be seen as support for the work done by Park and Westphal (2013) described above, which suggests that out-group biases could prevent inclusionary behaviours like mentoring. Park and Westphal (2013) also found that white male CEOs make negative and internal attributions about the poor performance of minority CEO-led firms. These perceptions and attributions are often reported in the media, leading to reputational damage for the minority CEO.

The "Matthew effect" is a concept that describes the tendency of high-status actors to derive greater rewards from similar accomplishments than low-status actors (Park \& Westphal 2013; Merton 1968). Within the realm of corporate executives, support has been found for the "inverse Matthew effect", where high-status leaders are held more accountable for poor performance (Jensen, Kim \& Kim 2011; Wade, Porac, Pollock \& Graffin 2006). In the Park and Westphal (2013) study minority CEOs suffered the "inverse Matthew effect' while white CEOs enjoyed positive returns from their status. This research found that certified (majority) CEOs received higher compensation than noncertified (minority) CEOs when performance was high but lower remuneration when 
performance was poor. Essentially, minority CEOs are more likely to have poor firm performance attributed to them personally. If this is indeed the case then by extension similar perception biases could directly affect the way boards evaluate the performance of their minority or PDI CEOs for the purposes of performance remuneration.

\subsubsection{Minority status as an advantage}

Hill et al (2014) investigated the question whether a CEO's minority status is a disadvantage or a source of benefit. They set off the many negative forces of intergroup relations theory against an economic resource-based argument, and found in favour of the latter. In their study of 1678 US firms over a 12-year period, they found that the rarity of the CEO's minority status benefited them overall with regard to higher levels of remuneration, but came at the cost of higher levels of job turnover. Using a longitudinal sample, support was found for the resource-based hypothesis regarding compensation that suggests CEOs benefit from their minority status to receive higher compensation than white male CEOs receive.

The findings of Hill et al (2014) are supported by a growing body of knowledge that is finding value in diversity. Richard, Murthi and Ismail (2007) note that "the most valuable natural resources in the world are not oil, diamonds, or even gold; it is the diverse knowledge, abilities, and skills that are immediately available from cultural diversity" ( $p$. 1213). Using a Tobin's q-test, they found a positive linear relationship between firm-level racial diversity and firm performance. Although there is sufficient research on the link between executive remuneration and firm performance, the evidence is inconclusive.

However, direct evidence of the effect of minority representation on corporate performance shows a decidedly mixed set of results. Some studies show a positive firm-performance relationship (Anderson, Reeb, Upadhyay \& Zhao 2011) while others produce either negative (Adams \& Ferreira 2009) or neutral (Carter, D'Souza, Simkins \& Simpson 2010) results. Miller and del Carmen Triana (2009) look beyond simple financial performance and indicate that the effect of minorities is more subtle and provides positive effects for firm reputation and corporate social performance.

Given South Africa's employment discrimination policies of the past, there is a need to review how South African black CEO's are remunerated for performance in comparison with their white counterparts. Such a study becomes increasingly relevant as more black individuals rise to the position of CEO.

\subsection{Research objectives}

The literature presents mixed findings on the relationship between CEO remuneration and race. The primary objective of this empirical research study was to determine if the race of the CEO has an effect on the degree of sensitivity of their remuneration to corporate performance. A further objective of the study was to obtain an understanding of the differences, if any, in the level and structure of remuneration between black and white CEOs. The intention was to determine the degree of remuneration equity between black and white CEOs in South Africa.

Given South Africa's transformation policies, it was hypothesised that there would be a significant difference in pay level and degree of performance sensitivity between black and white CEOs; and that the difference would be in favour of the black CEOs. Their minority/PDI status, together with their relative scarcity, was expected to lead to a stronger negotiating position when contracting their terms of employment with boards. This negotiating power could be used to increase pay level while reducing performance sensitivity, and thus earnings risk, involved in their remuneration. 
The research hypotheses are summarised as follows:

Research hypothesis 1: There is a significant difference in the pay-for-company performance sensitivities between black and white CEOs.

Pay for the CEOs is measured using their actual pay and bonuses and company performance is measured using several measures of company performance, namely:

- Return on Equity (ROE) and Profit after Tax (PAT).

- Headline Earnings per Share (HEPS) and Share Price (SP).

- Earnings before Interest, Tax, Depreciation and Amortisation (EBITDA).

Research hypothesis 2: There is a significant difference in the level and structure of CEO remuneration between black and white CEOs.

The diagram below depicts the way the major constructs will be measured.

Table 1

Major constructs

\begin{tabular}{|c|c|c|c|c|c|c|c|c|c|c|}
\hline \multirow{2}{*}{ Company performance measure } & \multicolumn{10}{|c|}{ Year } \\
\hline & 2004 & 2005 & 2006 & 2007 & 2008 & 2009 & 2010 & 2011 & 2012 & 2013 \\
\hline \multicolumn{11}{|l|}{ Return on Equity (ROE) } \\
\hline \multicolumn{11}{|l|}{ Profit after Tax (PAT) } \\
\hline \multicolumn{11}{|l|}{ Headline Earnings per Share (HEPS) } \\
\hline \multicolumn{11}{|l|}{ Share Price (SP) } \\
\hline \multicolumn{11}{|l|}{$\begin{array}{l}\text { Earnings before Interest, Tax, } \\
\text { Depreciation and Amortisation (EBITDA) }\end{array}$} \\
\hline \multirow{2}{*}{$\begin{array}{c}\text { Executive pay (fixed, short-term } \\
\text { incentives and total remuneration) }\end{array}$} & \multicolumn{10}{|c|}{ Year } \\
\hline & 2004 & 2005 & 2006 & 2007 & 2008 & 2009 & 2010 & 2011 & 2012 & 2013 \\
\hline \multicolumn{11}{|l|}{ Black Executive pay } \\
\hline White Executive pay & & & & & & & & & & \\
\hline
\end{tabular}

\subsection{The potential value-add of the study}

The potential value-add of this study is manifold. It could firstly quantify the remuneration and annual increases of the average South African CEO, contributing to an evidence-based evaluation of whether South African CEOs are excessively remunerated. Secondly, the study allows for a diagnosis of the degree to which corporate performance impacts this level of remuneration. The strength of this link, measured by pay-performance sensitivities, could help to determine whether CEOs are remunerated for the performance they deliver. Thirdly, the study could make a significant contribution to the literature on the relationship between CEO remuneration and race in South Africa. The findings are potentially of value to CEOs wanting to benchmark their pay and performance against demographic characteristics such as race with the aim of promoting fairness and equity.

\section{Research design}

\subsection{Research approach}

A quantitative and descriptive research approach was adopted for this study. A longitudinal analysis of pay-performance sensitivity metrics was conducted using archival secondary data from the McGregor BFA online financial database. The impact of race on these metrics was established using regression analysis. 


\subsection{Research method}

\subsubsection{Research participants}

The population of the study included black and white CEOs of South African listed companies who had served in this role for longer than two years within the last ten-year period. The time-frame was limited to ten years in order to ensure the relevance of the results. Tenure of at least two years was selected to enable a sufficient amount of information to be collected for each CEO.

The sample was limited to CEOs of listed companies as these companies are obligated to release both remuneration and financial performance information for the public record. Entities that were not headed by a CEO, but rather functioned as a trust managed by a board, were excluded (Shaw 2012). The sample consisted of all qualifying black CEOs $(n=19)$ and a random selection of 45 white CEOs. A full list of JSE CEOs was obtained and a number in sequence was assigned to each one. $A$ random number generator was used to pick CEOs from this list. Certain randomly selected white CEOs were excluded from the sample given that their remuneration was declared in a foreign currency. The decision to limit the sample to CEOs earning in Rand was taken in order to avoid any currency conversion complications. The black CEO sample is listed in Table 2 and the white CEO sample in Table 3. The use of simple random sampling to select the white CEOs ensured they all had the same probability of being selected and the sample was thus considered representative (Saunders \& Lewis 2011).

Table 2

Black CEO sample group

\begin{tabular}{|l|l|c|}
\hline \multicolumn{1}{|c|}{ Name } & \multicolumn{1}{|c|}{ Organisation } & Tenure (yrs) \\
\hline Respondent 1 & Gijima Group Ltd & 6 \\
\hline Respondent 2 & Brimstone Investment Corporation & 8 \\
\hline Respondent 3 & Mtn Group Limited & 4 \\
\hline Respondent 4 & Aveng Ltd & 8 \\
\hline Respondent 5 & Datacentrix Holdings Limited & 6 \\
\hline Respondent 6 & Tiger Brands Limited & 2 \\
\hline Respondent 7 & Platfields Limited & 2 \\
\hline Respondent 8 & TelkomSA Soc Ltd & 10 \\
\hline Respondent 9 & Business Connexion Group Limited & 7 \\
\hline Respondent 10 & Kagiso Media Limited & 6 \\
\hline Respondent 11 & Coronation Fund Managers Limited & 3 \\
\hline Respondent 12 & Rebosis Property Fund Limited & 7 \\
\hline Respondent 13 & Exxaro Resources Limited & 8 \\
\hline Respondent 14 & Firstrand Limited & 6 \\
\hline Respondent 15 & Arcelormittal SA Ltd & 4 \\
\hline Respondent 16 & Royal Bafokeng Platinum Ltd & 6 \\
\hline Respondent 17 & Adaptit Holdings Ltd & 2 \\
\hline Respondent 18 & Optimum Coal Holdings Limited & 5 \\
\hline Respondent 19 & The Don Group Limited & \\
\hline
\end{tabular}


Table 3

White CEO sample group

\begin{tabular}{|c|c|c|}
\hline Name & Organisation & Tenure (yrs) \\
\hline Respondent 1 & Pick N Pay Stores Limited & 5 \\
\hline Respondent 2 & Astrapak Limited & 8 \\
\hline Respondent 3 & Sentula Mining Ltd & 7 \\
\hline Respondent 4 & Convergenet Holdings Ltd & 6 \\
\hline Respondent 5 & EOH Holdings Ltd & 7 \\
\hline Respondent 6 & Wescoal Holdings Limited & 8 \\
\hline Respondent 7 & Harmony Gold Mining Company & 6 \\
\hline Respondent 8 & Impala Platinum Holdings Limited & 10 \\
\hline Respondent 9 & Illovo Sugar Limited & 10 \\
\hline Respondent 10 & RMB Holdings Limited & 10 \\
\hline Respondent 11 & Assore Limited & 8 \\
\hline Respondent 12 & Sephaku Holdings Limited & 4 \\
\hline Respondent 13 & A E C I Limited & 7 \\
\hline Respondent 14 & Merafe Resources Limited & 8 \\
\hline Respondent 15 & Lewis Group Limited & 5 \\
\hline Respondent 16 & Life Healthcare Group Holdings & 4 \\
\hline Respondent 17 & Invicta Holdings Limited & 10 \\
\hline Respondent 18 & Kumba Iron Ore Limited & 5 \\
\hline Respondent 19 & Pioneer Food Group Limited & 6 \\
\hline Respondent 20 & Clicks Group Limited & 7 \\
\hline Respondent 21 & Eqstra Holdings Limited & 6 \\
\hline Respondent 22 & Holdsport Limited & 3 \\
\hline Respondent 23 & Omnia Holdings Limited & 9 \\
\hline Respondent 24 & Hulamin Limited & 4 \\
\hline Respondent 25 & Mix Telematics Ltd & 6 \\
\hline Respondent 26 & Litha Healthcare Group Ltd & 3 \\
\hline Respondent 27 & Metair Investments Limited & 8 \\
\hline Respondent 28 & JSE Ltd & 5 \\
\hline Respondent 29 & Standard Bank Group Ltd & 9 \\
\hline Respondent 30 & Truworths International Limited & 10 \\
\hline Respondent 31 & Wilson Bayly Holmes-Ovcon Limited & 5 \\
\hline Respondent 32 & Anglo American Plat Ltd & 5 \\
\hline Respondent 33 & Massmart Holdings Limited & 9 \\
\hline Respondent 34 & Distell Group Limited & 10 \\
\hline Respondent 35 & Kap Industrial HIdgs Ltd & 6 \\
\hline Respondent 36 & Astral Foods Limited & 8 \\
\hline Respondent 37 & Clientele Limited & 6 \\
\hline Respondent 38 & Capitec Bank Holdings Limited & 8 \\
\hline Respondent 39 & \begin{tabular}{|l|} 
Mpact Limited \\
\end{tabular} & 3 \\
\hline Respondent 40 & Nictus Beperk & 5 \\
\hline Respondent 41 & Vodacom Group Ltd & 5 \\
\hline Respondent 42 & \begin{tabular}{|l|} 
Verimark Holdings Ltd \\
\end{tabular} & 8 \\
\hline Respondent 43 & York Timber Holdings Limited & 5 \\
\hline Respondent 44 & Afgri Limited & 5 \\
\hline Respondent 45 & Metrofile Holdings Limited & 9 \\
\hline
\end{tabular}




\subsubsection{Measuring instrument(s)}

The study focused on the relationship between three variables - race, corporate performance and CEO remuneration. The metrics selected for each of these variables follows.

CEO remuneration comprises several components. Whereas STIs, benefits and basic pay have quantifiable values in present terms, the valuation of the LTIs proved difficult. It was decided to exclude the LTIs awarded because the present value of the incentive needs to be calculated based on estimations of the future performance of the organisation (Core, Holthausen \& Larcker 1999). Many authors, including Ozkan (2011) and Lippert and Porter (1997) have argued for the inclusion of LTIs as the wealth generated through this channel can be significant. However numerous studies have produced results without including LTIs in their CEO pay basket (Nel 2012; Shaw 2012; Van Blerck 2012).

The following CEO remuneration metrics were included:

- Fixed Pay (FP) comprising basic salary and benefits.

- STIs.

- Total Remuneration (Fixed Pay plus STI's).

Corporate performance metrics were divided into accounting-based measures, marketbased measures and economic-based measures. The division of the metrics into these groups was driven by the literature, which suggests that a diversity of CEO pay-forperformance measures is considered best practice.

The selected corporate performance metrics included:

- Accounting-based measures: Return on Equity (ROE) and Profit after Tax (PAT).

- Market-based measures: Headline Earnings per Share (HEPS) and Share Price (SP).

- Economic-based measures: Earnings before Interest, Tax, Depreciation and Amortisation (EBITDA).

The definition of race was limited to black and white for the purposes of this study.

\subsection{Research procedure}

The study's archival focus required various extractions from secondary data sources. The McGregor BFA database was selected given the ready availability of the required metrics. This database collects published audited financial results of listed companies in a standard electronic format. In instances where the McGregor BFA database did not provide complete information, individual company annual reports were used to obtain the relevant data manually. As listed companies within the sampling frame are legally required to disclose certain regulated financial and remuneration information, the validity of this type of secondary data is considered to be high (Nel 2012; Shaw 2012; Van Blerck 2012).

\subsection{Statistical analysis}

The database set was analysed using the SPSS statistical software program. Initial descriptive statistics were performed on the database to obtain a coarse and granular picture of the main features of each of the samples drawn. The database was tested for internal reliability using the Cronbach's Alpha test. The validity of the database was ensured by eliminating any bias during the data collection phase and using random sampling of audited and published financial results. 
A combination of regression analysis and Spearman's rank coefficient was used to determine the relationship and strength of association between CEO remuneration and corporate performance. The remuneration data were tested for normality using the Shapiro-Wilk test (Pallant 2010). A test consisting of a combination of a standard t-Test (normal/parametric) and a Mann-Whitney Test (non-normal/non-parametric) was then conducted. To analyse the effect of race a Factorial Analysis of Variance (two-way between-group ANOVA) method was used. In order to control for the size of the company the application of an Analysis of Covariance (ANCOVA) test was conducted.

The above-mentioned statistical tests are summarised in Table 4. To improve the robustness of the statistical analysis, each statistical test was assigned a confirmation test of a different type.

Table 4

Statistical tests per research hypothesis

\begin{tabular}{|l|l|l|l|l|}
\hline $\begin{array}{c}\text { Research } \\
\text { Hypothesis }\end{array}$ & Reliability Test & Normality Test & \multicolumn{1}{|c|}{ Statistical Test } & Confirmation Test \\
\hline One & Cronbach's & Shapiro-Wilk & Spearman's Rank & Regression \\
\hline Two & Cronbach's & Shapiro-Wilk & Indep. t-Test/Mann-Whit. & Two-factor ANOVA \\
\hline
\end{tabular}

\section{Results}

\subsection{Description of sample}

A total of 19 black CEOs met the selection criteria and comprised the black CEO sample. Their median tenure over the period studied (2004-2013) was 6 years (average of 5.78 years with a standard deviation of 2.49 years) and they headed organisations with a market capitalisation median of R4 410325000 (average of R48 billion with a standard deviation of R111 billion). The large variance in market deviation was caused by the inclusion of Dabenqwa (MTN) and Nxasana (Firstrand) in the sample.

The white CEO sample included 45 randomly selected CEOs meeting the selection criteria and represented a median tenure of 6 years (average of 6.69 years with a standard deviation of 2.11 years). The median market capitalisation of the organisations represented in the white sample was R8 765460000 (average of R27 billion with a standard deviation of R48 billion).

Although the median CEO tenure of each sample group may appear similar, approximately half $(48.89 \%)$ of the white CEO sample had tenure in excess of 7 years. The proportion of black CEOs with a similar length of service accounted for approximately one-third $(36.84 \%)$ of the group. It would therefore appear that a higher portion of white CEOs have longer tenure than black CEOs.

\subsection{Measures of corporate performance}

The data set used to determine corporate performance measures was tested for reliability using the Cronbach's Alpha test. The results are presented in Table 5 and indicate strong reliability for each measure of corporate performance.

Table 5

Reliability test results - corporate performance

\begin{tabular}{|c|c|c|c|c|}
\hline ROE & PAT & HEPS & SP & EBITDA \\
\hline 0.882 & 0.945 & 0.905 & 0.961 & 0.983 \\
\hline
\end{tabular}




\subsection{Accounting-based performance measures}

The accounting-based performance measures defined for this study were ROE and PAT. The ROE for the company sample showed similar declines in both the mean and the median values of $7.45 \%$ and $6.10 \%$ per year respectively. Thus the return seen by equity holders reduced during the period of observation. The median ROE values per race per year indicate that post-2009 ROE for black-headed organisations saw a decrease of $2.94 \%$ per year for this period. White-headed organisations also registered a negative trend in their ROE of $-1.84 \%$ over the same post-2009 period.

PAT values within the company sample showed a big difference between the mean and median values. Only the median values were considered for analysis to remove disruptive outliers. The median PAT has risen from R159 289000 to R491 464000 over the ten-year period, representing a growth of $11.93 \%$ per year. In 2011 the peak median PAT value was R530 967 000. Despite the growth in PAT year-on-year, ROE saw a decline over the same period. This could be explained by a general change in operating efficiencies, asset efficiencies or leverage. After 2009 both black- and whiteheaded companies saw flat annual growth $(1.27 \%$ and $0.81 \%$ respectively) in their PAT values.

\subsection{Market or economic-based performance measures}

The market-based performance measures defined for this study were EBITDA, HEPS and the percentage movement in the SP. The median HEPS increased by $5 \%$ per year from 110 c in 2004 to 184 c by 2013 . The mean HEPS show far more variability than the median, especially from 2006 to 2009 . The highest median HEPS value (208c) was seen in 2008 and was not surpassed after the recession. An examination of HEPS per year per race shows that post-2009 the growth was $-1.71 \%$ and $4.08 \%$ for blackheaded and white-headed companies respectively.

The median and mean changes in SP were aligned and clearly reflected the impact of the recession from 2007 to 2010 . Before 2008 share price values were increasing by $40 \%$ to $50 \%$ year-on-year. After 2010 the rate of growth in the value of shares was much slower. For the period 2007 to 2010 the median change in the rate of growth of the SP was $-19.53 \%$. Reviewing the absolute value of the SP over the total period saw an annual average appreciation of $13.57 \%$. When looking at the SP per year per race it is evident that white-headed companies grew at a faster rate $(2.90 \%$ per year post$2009)$ than black-headed companies (-0.20\% for the same period).

Given the large standard deviation evident in the data set of EBITDA values, only the median was considered for analysis. The median EBITDA value rose from R426 414 000 in 2004 by an annual average rate of $6.51 \%$ to R801 454000 by 2013. EBITDA values, like PAT, peaked in 2011. In terms of race, the variability seen before 2009 may be attributed to the small number of black-headed companies in the sample. After 2009 the absolute median values of EBITDA grew per year by $1.49 \%$ for white-headed companies and by $-3.01 \%$ for black-headed companies.

\subsection{Measures of executive remuneration}

The descriptive statistics included cannot be used to infer remuneration characteristics of the population of CEOs. The reason for this is the small sample size once the number of CEOs studied is divided by year, especially prior to 2008. Tables 6 and 7 show the remuneration data for each group over the full period covered by the present study. 
Table 6

Descriptive statistics - fixed pay (R000) - black sample

\begin{tabular}{|l|r|r|r|r|r|r|r|r|r|r|}
\hline Measure & $\mathbf{2 0 0 4}$ & $\mathbf{2 0 0 5}$ & $\mathbf{2 0 0 6}$ & $\mathbf{2 0 0 7}$ & $\mathbf{2 0 0 8}$ & $\mathbf{2 0 0 9}$ & $\mathbf{2 0 1 0}$ & $\mathbf{2 0 1 1}$ & $\mathbf{2 0 1 2}$ & $\mathbf{2 0 1 3}$ \\
\hline Count (n) & 2 & 2 & 5 & 7 & 12 & 14 & 16 & 18 & 18 & 16 \\
\hline Min & 1235 & 1211 & 1145 & 1459 & 431 & 684 & 748 & 806 & 855 & 710 \\
\hline Max & 2129 & 2916 & 4000 & 4186 & 4620 & 5198 & 5868 & 8036 & 10083 & 12677 \\
\hline Mean & 1682 & 2064 & 2293 & 2561 & 2717 & 2980 & 3251 & 3588 & 4294 & 4799 \\
\hline Std Dev. & 632 & 1206 & 1381 & 1279 & 1420 & 1444 & 1577 & 2006 & 2768 & 3189 \\
\hline Median & 1682 & 2064 & 1476 & 1756 & 2833 & 3029 & 3123 & 3161 & 3538 & 4204 \\
\hline
\end{tabular}

Table 7

Descriptive statistics - fixed pay (R000) - white sample

\begin{tabular}{|l|r|r|r|r|r|r|r|r|r|r|}
\hline Measure & $\mathbf{2 0 0 4}$ & $\mathbf{2 0 0 5}$ & $\mathbf{2 0 0 6}$ & $\mathbf{2 0 0 7}$ & $\mathbf{2 0 0 8}$ & $\mathbf{2 0 0 9}$ & $\mathbf{2 0 1 0}$ & $\mathbf{2 0 1 1}$ & $\mathbf{2 0 1 2}$ & $\mathbf{2 0 1 3}$ \\
\hline Count (n) & 7 & 11 & 19 & 24 & 33 & 39 & 43 & 45 & 44 & 36 \\
\hline Min & 885 & 947 & 009 & 252 & 285 & 242 & 1223 & 1266 & 992 & 798 \\
\hline Max & 4106 & 4331 & 5118 & 5197 & 6318 & 7104 & 7624 & 8030 & 9196 & 9943 \\
\hline Mean & 2089 & 2102 & 2183 & 2416 & 2787 & 3174 & 3459 & 3687 & 4054 & 4180 \\
\hline Std Dev. & 1147 & 1019 & 1020 & 1017 & 1288 & 1377 & 1628 & 1637 & 2012 & 1984 \\
\hline Median & 1528 & 1786 & 2066 & 2080 & 2506 & 2840 & 3200 & 3470 & 3741 & 4003 \\
\hline
\end{tabular}

Three components of executive pay were tested for internal reliability. The results are presented in Table 8 and show strong internal reliability.

Table 8

Reliability test results - remuneration

\begin{tabular}{|c|c|c|}
\hline Fixed Pay & Short-Term Incentives & Total Remuneration \\
\hline 0.882 & 0.945 & 0.905 \\
\hline
\end{tabular}

The Shapiro-Wilk test was conducted on the remuneration data as a test for normality. The appearance of normality differed from year to year across all three measures of executive pay studied. The normality test failed on the black CEO sample for the years 2004 to 2006 given the small sample sizes for these years.

Fixed pay: Figure 1 shows the relative frequency distribution for the fixed pay of black and white CEOs. Most black CEOs earned from R3 000000 to R3 999000 while most white CEOs earned between R5 000000 and R5 999 000. In the tail above R6 000000 there are relatively more black CEOs than white.

The median fixed pay of the black sample increased from R2 833000 in 2008 to R4 204000 in 2013, which represented an average increase of $17.2 \%$ per year. The annual percentage increase seen in the mean fixed pay reflects an increase of $12.6 \%$. The median fixed pay of the white sample increased from R2 506000 in 2008 to R4 003000 in 2013, which represents an average increase of $11.6 \%$ per year. This lags behind the increases experienced by black CEOs over the same period. In 2010 black CEO mean fixed pay underperformed white CEO by $6.0 \%$; however, this was reversed to a $14.8 \%$ premium by 2013 .

Short-term incentives: The mean STI paid to black CEOs was R2 241000 in 2008, which increased by $4.6 \%$ per annum to R3 053000 in 2013. The maximum STI paid was R18 100000 in 2013, which is more than double that paid in 2010. White CEOs saw an increase of $6.7 \%$ per annum from 2008 to 2013 in their mean STI pay, which rose from R2 698000 to R3 289000 over the period. The maximum STI paid to a white CEO within the sample was R19 134000 in 2009. 
Figure 1

Descriptive Statistics - Histogram of Fixed Pay

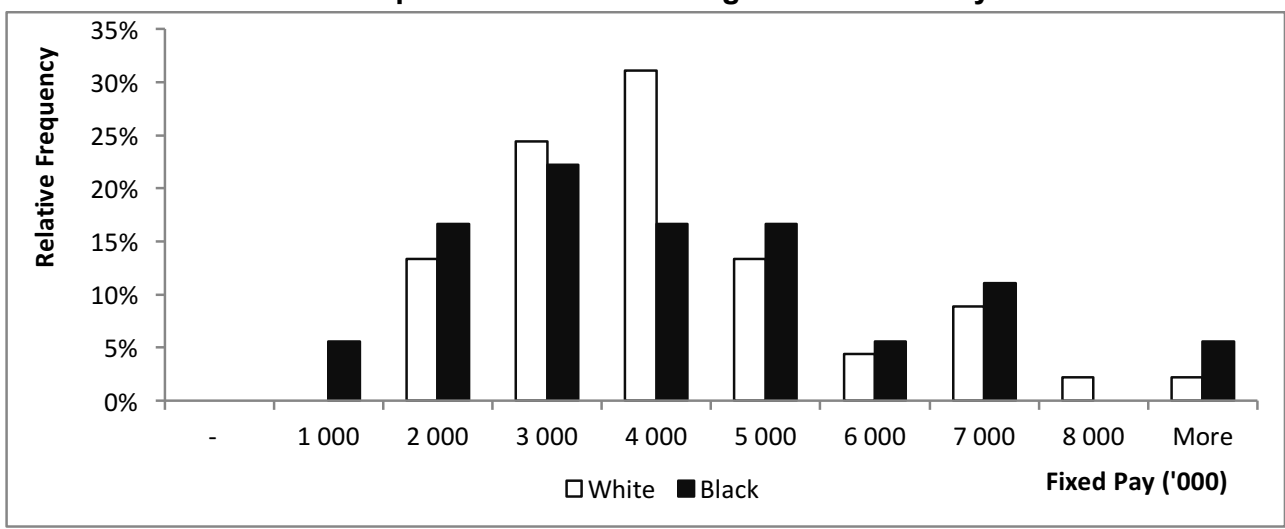

Total remuneration: Black CEOs' mean total remuneration rose from R5 024000 in 2008 to R8 751000 in 2013. This equates to an annual average increase in their total remuneration of $9.7 \%$ for this period. The standard deviation of these means progressed from R3 633000 in 2008 to R8 318000 by 2013, showing a growing variation in the amounts paid. Mean total remuneration for white CEOs was R5 801000 in 2008 and increased to R8 278000 by 2013 . This represents a $7.3 \%$ annual average increase. The standard deviation for the same period widened slightly from R4 434000 to R5 527000 .

Figure 2 shows the development of each group's mean total remuneration over the period 2004 to 2013. The lower growth per year of the white CEOs' total remuneration can be seen for the period 2008 to 2013. After 2008, 2013 was the first year the mean total remuneration of black CEOs was greater than that of white CEOs for the respective groups. Mean total remuneration of black CEOs was largely stable during the period 2005-2010, dipping slightly during the global recession years of 2008 and 2009. The mean total remuneration of white CEOs continued to increase during the recession period, dipping only slightly in 2010 . Since 2010 both groups have moved upwards in unison.

Figure 2

Mean CEO total remuneration per sample

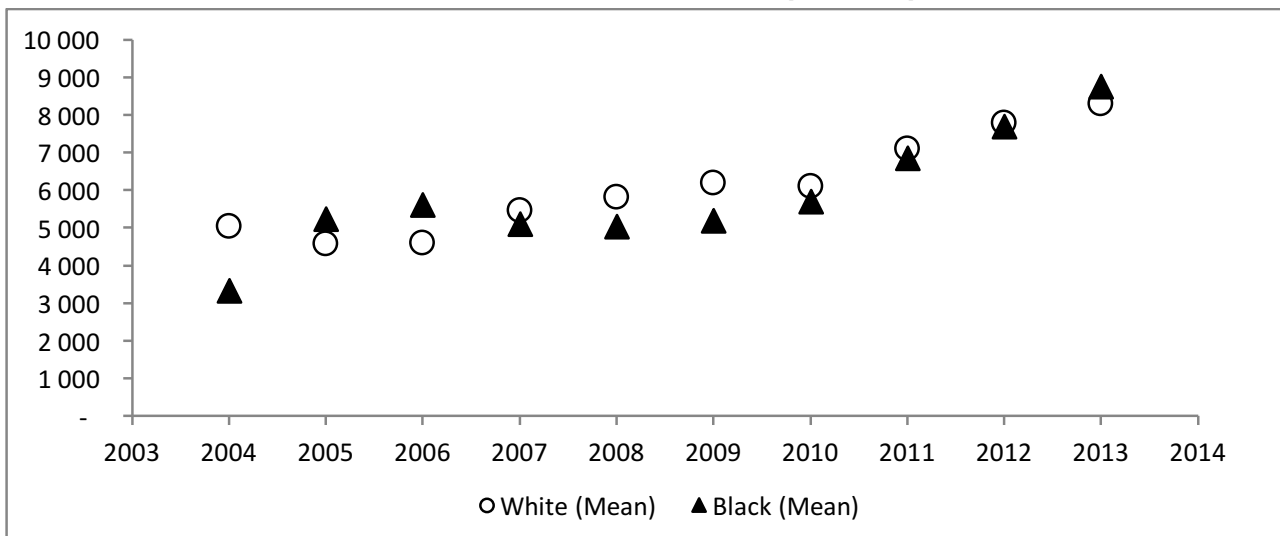




\subsection{Results for Research Hypothesis 1}

Hypothesis 1 required the evaluation of the pay for company performance sensitivity for each race group. Spearman's Rank Test was used and linear regression was then conducted as a confirmation test. Results are presented for Total Remuneration (fixed pay plus short-term incentive) because that is the figure most companies and analysts use for benchmarking the quantum of executive remuneration. Given the small sample of black CEOs prior to 2009, only remuneration and performance data since 2009 have been included.

\subsection{Total remuneration correlations by race}

As with the CEO FP component, only PAT, HEPS and EBITDA showed a significant $(p<0.01)$ and strong correlation with total remuneration received. ROE and SP failed to provide any significant correlation for this measure. Table 9 shows that black and white CEO total remuneration showed correlations of similar magnitude with PAT and HEPS. The highest significant correlation recorded (0.913) was for the relationship between the total remuneration of white CEOs and EBITDA. Overall black CEO total remuneration was strongly correlated with PAT (0.712), EBITDA (0.674) and HEPS (0.652). White CEO total remuneration was strongly correlated with EBITDA (0.913), PAT (0.765) and HEPS (0.740).

Table 9

Spearman's rank correlation coefficients per race - total remuneration

\begin{tabular}{|l|c|c|c|c|c|}
\hline \multicolumn{1}{|c|}{ Measure } & $\mathbf{2 0 0 9}$ & $\mathbf{2 0 1 0}$ & $\mathbf{2 0 1 1}$ & $\mathbf{2 0 1 2}$ & $\mathbf{2 0 1 3}$ \\
\hline ROE - Black & 0.039 & 0.225 & $0.599^{*}$ & 0.387 & 0.346 \\
\hline ROE - White & 0.070 & -0.12 & -0.18 & -0.23 & 0.135 \\
\hline PAT - Black & $0.71^{* *}$ & $0.73^{* *}$ & $0.73^{* *}$ & $0.69^{* *}$ & $0.67^{* *}$ \\
\hline PAT - White & $0.77^{* *}$ & $0.81^{* *}$ & $0.87^{* *}$ & $0.66^{* *}$ & $0.69^{* *}$ \\
\hline HEPS - Black & $0.589^{*}$ & $0.65^{* *}$ & $0.67^{* *}$ & $0.71^{* *}$ & $0.625^{*}$ \\
\hline HEPS - White & $0.69^{* *}$ & $0.74^{* *}$ & $0.86^{* *}$ & $0.66^{* *}$ & $0.73^{* *}$ \\
\hline SP - Black & $0.599^{*}$ & $0.74^{* *}$ & 0.506 & 0.234 & 0.131 \\
\hline SP - White & -0.07 & -0.13 & $-0.33^{*}$ & -0.23 & 0.148 \\
\hline EBITDA - Black & $0.79^{* *}$ & $0.590^{*}$ & $0.66^{* *}$ & $0.60^{* *}$ & $0.70^{* *}$ \\
\hline EBITDA - White & $0.90^{* *}$ & $0.89^{* *}$ & $0.92^{* *}$ & $0.90^{* *}$ & $0.93^{* *}$ \\
\hline
\end{tabular}

${ }^{*} p<0.05$ (2-tailed); ${ }^{* *} p<0.01$ (2-tailed)

Table 10 indicates that as with the other pay components studied, the variation in total remuneration was better explained by the independent variables in the black CEO group. EBITDA and PAT accounted for $46.3 \%$ and $41.0 \%$ respectively of the variation seen in black CEO total remuneration. In contrast, these variables accounted for only $14.5 \%$ and $16.2 \%$ of the variation represented in the white CEO group. HEPS was the only corporate performance measure that produced similar R-squared values between the groups.

In summary, it is clear that the same dominant corporate performance measures (EBITDA, PAT and HEPS) are strongly correlated with the remuneration components for both groups. Although the order may change, depending on the component EBITDA, PAT and HEPS impacted the remuneration of both groups. The total remuneration of black CEOs showed greater sensitivity to these measures than that of white CEOs. 
Table 10

Regression R-squared values per race - total remuneration

\begin{tabular}{|l|l|l|l|l|l|}
\hline \multicolumn{1}{|c|}{ Measure } & $\mathbf{2 0 0 9}$ & $\mathbf{2 0 1 0}$ & $\mathbf{2 0 1 1}$ & $\mathbf{2 0 1 2}$ & $\mathbf{2 0 1 3}$ \\
\hline ROE - Black & 0.010 & 0.013 & 0.220 & 0.053 & 0.041 \\
\hline ROE - White & $0.126^{*}$ & 0.073 & 0.062 & 0.060 & $0.20^{* *}$ \\
\hline PAT - Black & 0.282 & $0.369^{*}$ & 0.164 & $0.47^{* *}$ & $0.75^{* *}$ \\
\hline PAT - White & 0.085 & $0.129^{*}$ & $0.20^{* *}$ & 0.028 & $0.36^{* *}$ \\
\hline HEPS - Black & 0.187 & 0.234 & 0.067 & 0.128 & 0.176 \\
\hline HEPS - White & $0.154^{*}$ & 0.090 & 0.084 & 0.080 & $0.25^{* *}$ \\
\hline SP - Black & 0.243 & $0.412^{*}$ & 0.189 & 0.020 & 0.000 \\
\hline SP - White & 0.011 & 0.001 & 0.010 & 0.004 & 0.000 \\
\hline EBITDA - Black & $0.424^{*}$ & 0.273 & 0.098 & $0.71^{* *}$ & $0.80^{* *}$ \\
\hline EBITDA - White & 0.010 & 0.057 & $0.27^{* *}$ & 0.065 & $0.31^{* *}$ \\
\hline
\end{tabular}

${ }^{*} \mathrm{p}<0.05$ (2-tailed); ${ }^{* *} \mathrm{p}<0.01$ (2-tailed)

\subsection{Results for research hypothesis 2}

This hypothesis involved testing for the presence of significant differences between the level and structure of the remuneration of each race group. It was evident from the normality test results that the appearance of normality differed from year to year across all three measures of executive pay studied. Thus in answering research hypothesis 2 a mixture of parametric and non-parametric tests was required due to the shape and parameters of the data.

\subsection{Effect of race on remuneration}

Table 11 reflects the p-values of the t-Test and the Mann-Whitney tests conducted on the three aspects of executive remuneration.

Table 11

p-Values for the two sample independent t-Tests and Mann-Whitney tests

\begin{tabular}{|l|l|c|c|c|c|c|c|c|c|c|c|}
\hline \multicolumn{2}{|c|}{ Test } & $\mathbf{2 0 0 4}$ & $\mathbf{2 0 0 5}$ & $\mathbf{2 0 0 6}$ & $\mathbf{2 0 0 7}$ & $\mathbf{2 0 0 8}$ & $\mathbf{2 0 0 9}$ & $\mathbf{2 0 1 0}$ & $\mathbf{2 0 1 1}$ & $\mathbf{2 0 1 2}$ & $\mathbf{2 0 1 3}$ \\
\hline \multirow{2}{*}{ Fixed } & t Test & 0.278 & 0.486 & 0.437 & 0.395 & 0.441 & 0.333 & 0.330 & 0.427 & 0.371 & 0.241 \\
\cline { 2 - 12 } & Mann-Whit. & 0.385 & 0.422 & 0.322 & 0.362 & 0.469 & 0.385 & 0.452 & 0.375 & 0.494 & 0.310 \\
\hline \multirow{2}{*}{ STI } & t Test & 0.281 & 0.401 & 0.426 & 0.461 & 0.327 & 0.264 & 0.407 & 0.493 & 0.377 & 0.440 \\
\cline { 2 - 11 } & Mann-Whit. & 0.500 & 0.277 & 0.261 & 0.388 & 0.464 & 0.343 & 0.493 & 0.147 & 0.343 & 0.086 \\
\hline \multirow{2}{*}{ Total } & t Test & 0.259 & 0.440 & 0.345 & 0.424 & 0.278 & 0.155 & 0.329 & 0.434 & 0.479 & 0.419 \\
\cline { 2 - 11 } & Mann-Whit. & 0.385 & 0.500 & 0.348 & 0.462 & 0.341 & 0.351 & 0.367 & 0.287 & 0.283 & 0.289 \\
\hline
\end{tabular}

The alpha value selected for both tests was 0.05 and for all remuneration combinations across the period of the study, the $p$-value was greater than 0.05 . This indicates that there is no significant difference between the sample means across the measures of executive remuneration. Thus the attribute of race does not appear to impact significantly on the mean remuneration received by either group.

\subsection{Effects of company size on remuneration}

In order to control for company size, the application of an Analysis of Covariance (ANCOVA) test was conducted. For the test total assets were selected as the proxy for size and were tested against total remuneration and race for the period 2009 to 2013. This period was selected on the basis of the adequate sample sizes per year. Results are shown in Table 12. 
Table 12

p-Values of the ANCOVA test

\begin{tabular}{|l|c|c|c|c|c|c|}
\hline \multicolumn{1}{|c|}{ Measure } & $\mathbf{2 0 0 9}$ & $\mathbf{2 0 1 0}$ & $\mathbf{2 0 1 1}$ & $\mathbf{2 0 1 2}$ & $\mathbf{2 0 1 3}$ & Significant \\
\hline Treatment (Race) & 0.3836 & 0.6061 & 0.7768 & 0.8791 & 0.4174 & No \\
\hline Covariate (Size) & 0.4670 & 0.1540 & 0.0025 & 0.0130 & 0.0001 & Yes \\
\hline
\end{tabular}

The results of the ANCOVA test confirm that race is not significant (treatment $p$-values $>0.05$ ) in terms of mean total remuneration as per the Mann-Whitney tests. Results also confirm that the covariant of company size has a significant influence ( $p$-values $<0.05$ ) on the mean total remuneration of the CEOs in the two samples.

\section{Discussion}

The primary objectives of this study were to determine the effect of race on CEO payperformance sensitivity and to investigate the differences between the level and structure of remuneration between black and white CEOs in South Africa. The intention was to determine the degree of remuneration equity between black and white CEOs. The study makes a significant contribution to the literature on the relationship between CEO remuneration and race in South Africa. The findings of no significant difference in remuneration between black and white CEOs are of value to CEOs wanting to benchmark their pay and performance against demographic characteristics, such as race, with the aim of promoting fairness and equity. The findings could influence corporate governance on CEO pay by providing evidence of whether discrimination or bias is displayed in designing optimal performance and remuneration contracts. The present findings are now discussed relative to the review of the literature.

\subsection{Research hypothesis 1}

Research hypothesis 1 predicted a significant difference in the pay-for-company performance sensitivities between black and white CEOs. Results show that the same dominant corporate performance measures (EBITDA, PAT and HEPS) are strongly correlated with the remuneration components for both race groups. Although the order may change, depending on the component, EBITDA, PAT and HEPS impacted the remuneration of both groups for fixed pay and total remuneration.

A significant difference between the race groups was found in the performance measures impacting STIs. EBITDA and PAT both accounted for more than $40 \%$ of the variance seen for black CEOs. The same measures did not significantly account for the variance seen in STIs for white CEOs. ROE and HEPS (both accounting for approximately $12 \%$ ) were significant for white CEOs.

White CEO incentives therefore appear to be more closely linked to shareholders' perceptions of performance through the ROE and HEPS measures, whereas black CEO incentives appear to relate more to operational and managerial perceptions of performance. The literature neither supports nor refutes this finding and it is suggested that further research be conducted to validate this result.

Although similar corporate performance measures impacted the remuneration of both race groups, the degree of variance explained is different. The differences show that black CEO remuneration is more sensitive, by a factor of 2 to 3 times, than that of their white counterparts to the corporate performance measures chosen. The "inverse Matthew effect" supported by Park and Westphal (2013) and Jensen et al (2011) provides a partial explanation for the difference in sensitivities seen. This effect was 
used to describe the appearance of increased pay sensitivity of minority CEOs to poor corporate performance.

After 2009 companies within the black CEO sample generally performed less well than companies within the white CEO sample on four of the five measures. It should be noted that the intention is not to link race to organisational performance as that lies outside the objectives of this study and the analysis done. However, the increased sensitivity reflected within the black CEO sample combined with the poorer median performance could indicate, as Park and Westphal (2013) suggest, that poor firm performance is more likely to be attributed to minority CEOs personally.

The limitation of the above use of the "inverse Matthew effect" is that it assumes directional and asymmetrical sensitivity of pay-for-performance between the races. Hence it would serve to explain why black CEO pay is are more sensitive than that of their white colleagues to poor corporate performance yet white CEO pay is more sensitive to good corporate performance. Directional sensitivity was not explored in this study and would make for an interesting further study.

When considering the lower pay-performance sensitivity found for white CEOs, the "Matthew effect" would indicate that white CEOs are held less liable for poorer performance and are overly attributed for good corporate performance (Park \& Westphal 2013). The annual growth rates in the white-CEO sample are also considered poor given that the growth in ROE and EBITDA was negative and that PAT experienced near-zero growth. Given the poor performance and less sensitive remuneration, it appears that median white CEOs are held less liable for poor corporate performance. Although Show and Zhang (2010) do not account specifically for race, their study does support the finding that CEO remuneration is generally not punished for poor performance.

An alternative explanation is that the corporate performance measures chosen in this study are dissimilar to those used by boards and remuneration committees to reward white CEO performance. This would mean that the study failed to capture the correct basket of measures that relate to the remuneration of white CEOs. Should this be the case then it would be possible to conclude only that white and black CEOs may be incentivised on a different set of corporate performance measures. The probability of misrepresenting the corporate performance measures for white CEOs is limited given that the selection of measures was based on the extensive and accepted body of knowledge within this field. Recognised studies consulted include De Wet (2013), Conyon and He (2011),Wang and Xiao (2011) and Tosi et al (2000).

\subsection{Research hypothesis 2}

Research hypothesis 2 predicted a significant difference in the level and structure of CEO remuneration between black and white CEOs. The intention of this objective was to determine the degree of remuneration equity between black and white CEOs in South Africa. Results show that the difference in mean remuneration received by black and white CEOs was not statistically significant. This was supported by the closeness of the median total remuneration received by each group. However, when the variance within each race group was considered, the similarity in the remuneration packages became less marked. Black CEOs showed far higher variance in their remuneration than their white counterparts.

When the cause of the variance was analysed it was found that the black CEO sample had several outliers distorting the mean black total remuneration. The effect of 
these outliers was tested and the mean black total remuneration dropped by $24 \%$ with the outliers neutralised. It could be argued that the outliers do not accurately depict the remuneration of the average black CEO. In that case the findings would indicate the presence of the "inverse Matthew effect" and support Kulich et al's (2011) findings that minority status is in fact an invisible barrier preventing equitable compensation. By extension this could further support Scheepers, Spears, Doosje \& Manstead (2006) and indicate the presence of intergroup relations theory whereby easily discoverable features, such as race, play a greater role than merit-based capabilities or performance when setting remuneration and rewards.

The lack of racial significance regarding CEO remuneration was again established once each group's remuneration was controlled for firm size. This was an important litmus test and showed that firm size was a far more significant factor in CEO remuneration than race. This is well supported by many studies, including that of Tosi et al (2000).

\subsection{Conclusion and recommendations for action}

In absolute terms there is no significant difference in the level of remuneration received by black and white CEOs. This was true for all the various components of remuneration studied. It is therefore concluded that in absolute terms remuneration equity appears to be present between black and white CEOs. Black and white CEOs show sensitivity to a similar basket of corporate performance measures which represented a balance between accounting-based and non-accounting-based measures. It is therefore concluded that race does not affect the selection by boards of corporate performance measures against which to incentivise CEOs. Black CEO pay was significantly more sensitive and variable than that of their white CEO counterparts. It is therefore concluded that boards and remuneration committees appear to structure black CEO remuneration with a greater element of performance sensitivity.

Corporate history contains many examples of inappropriately incentivised CEOs and the effects of inappropriate remuneration. An important element not directly covered in this study is the inclusion of risk-based measures in the basket of measures impacting remuneration. It is recommended that the risk context of the organisation should be quantified with an appropriate measure and included as a counterbalance to ensure that the organisational performance achieved will be sustained in the long term. Once the organisation has identified relevant measures of performance, these need to be put in place with realistic and fairly achievable targets in terms of the desired payperformance sensitivities. Such internal pay-performance sensitivity needs to be calculated and analysed in a regular fashion that includes benchmark comparisons with appropriate comparators.

There are several important policy recommendations that emanate from this research. Firstly, performance targets and pay-performance sensitivity analyses should be presented as part the remuneration report that forms part of the annual financial reports. This form of disclosure would allow a certain level of public accountability to ensure reasonable and justifiable CEO remuneration. Secondly, there is no need for further legislation concerning remuneration. Thirdly, the BBBEE targets should cease to exist at executive level because pay parity and equal CEO performance have been achieved. Finally, it is recommended that labour movements familiarise themselves with the findings of this research and cease to claim that there is a difference in remuneration for white and black CEOs. 
An area for future research would be to repeat this study further down the organisation. It is speculated that one would find a similar result.

Boards looking to appoint black or minority CEOs should continue to remunerate in an equitable and fair manner and be aware of cognitive biases such as the "inverse Matthew effect" and other social out-group biases, especially when evaluating performance. If the above recommendations are implemented in conjunction with this then CEO performance-sensitive remuneration could be largely determined off an objective base.

\section{List of references}

Abowd, JM. 1990. Does performance-based managerial compensation affect corporate performance? Industrial and Labour Relations Review 43:52-73.

Adams, RB \& Ferreira, D. 2009. Women in the boardroom and their impact on governance and performance. Journal of Financial Economics 94(2):291-309.

Anderson, RC, Reeb, DM, Upadhyay, A \& Zhao, W. 2011. The economics of director heterogeneity. Financial Management 40(1):5-38.

Baker, GP \& Hall, BJ. 1998. CEO incentives and firm size. Journal of Labor Economics 22(4):767-798.

Barkema, HG \& Gomez-Mejia, LR. 1998. Managerial compensation and firm performance: A general research framework. Academy of Management Journal 41(2):135-145.

Bruce, A, Buck, T \& Main, BG. 2005. Top executive remuneration: A view from Europe. Journal of Management Studies 42(7):1493-1506.

Bussin, M. 2011. The remuneration handbook for Africa. Randburg: Knowres.

Bussin, M. 2013. Grasping the thorny issue of executive remuneration. Johannesburg: $21^{\text {st }}$ Century.

Bussin, M. 2015. "CEO Pay performance sensitivity in the South African context" South African Journal of Economic and Management Sciences 18(2):1-13.

Bussin, M \& Modau, MF. 2015. The relationship between Chief Executive Officer (CEO) remuneration and financial performance in South Africa between 2006 and 2012. SA Journal of Human Resource Management 13(1):1-18.

Bussin, M \& Nel, M. 2015. Relationship between CEO remuneration and company financial performance in the South African retail and consumer goods sector. Acta Commercii 15(1):1-11.

Carter, DA, D'Souza, F, Simkins, BJ \& Simpson, WG. 2010. The gender and ethnic diversity of US boards and board committees and firm financial performance. Corporate Governance: An International Review 18(5):396-414.

Conyon, MJ \& He, L. 2011. Executive compensation and corporate governance in China. Journal of Corporate Finance 17(4):1158-1175.

Cooper, MJ, Gulen, H \& Rau, PR. 2010. Performance for pay? The relation between CEO incentive compensation and future stock price performance. Cambridge, MA: University of Cambridge. 
Core, JE, Holthausen, RW \& Larcker, DF. 1999. Corporate governance, chief executive officer compensation, and firm performance. Journal of Financial Economics 51(3):371-406.

De Wet, J. 2013. Executive compensation and the EVA and MVA performance of South African listed companies. Southern African Business Review 16(3):57-80.

Firer, C, Ross, S, Westerfield, R \& Jordan, B. 2012. Fundamentals of Corporate Finance. 5th South African edition. Sydney: McGraw-Hill.

Gevers, E. 2012. Adherence to the spirit of corporate governance: The ethics of executive remuneration. Johannesburg: University of Johannesburg.

Ghosh, A. 2006. Determination of executive compensation in an emerging economy: Evidence from India. Emerging Markets Finance and Trade 42(3):66-90.

Goodman-Bhyat, D. 2013. Jack Hammer Executive Report, vol. 1. Cape Town: Jack Hammer Executive Headhunters.

Graham, M \& Winfield, J. 2007. Understanding financial statements. $2^{\text {nd }}$ edition. Cape Town: Cape Business Seminars.

Hartley, C, Firer, C \& Ford, JC. 2011. Business accounting and finance for managers: An introduction. 5th SA edition. Johannesburg: Witwatersrand University Press.

Hill, AD, Upadhyay, AD \& Beekun, RI. 2014. Do female and ethnically diverse executives endure inequity in the CEO position or do they benefit from their minority status? An empirical examination. Strategic Management Journal 36(8):1115-1134.

Hillman, AJ, Cannella, AA \& Harris, IC. 2002. Women and racial minorities in the boardroom: How do directors differ? Journal of Management 28(6):747-763.

Hillman, AJ, Shropshire, C \& Cannella, AA. 2007. Organizational predictors of women on corporate boards. Academy of Management Journal 50(4):941-952.

Jensen, M, Kim, BK \& Kim, H. 2011. The importance of status in markets: A market identity perspective. Status in Management and Organizations 48(2): 87-117.

Kulich, C, Trojanowski, G, Ryan, MK, Alexander Haslam, S \& Renneboog, LD. 2011. Who gets the carrot and who gets the stick? Evidence of gender disparities in executive remuneration. Strategic Management Journal 32(3):301-321.

Larcker, DF \& Tayan, B. 2011. Seven myths of corporate governance Stanford University Closer Look Series: Topics, Issues and Controversies in Corporate Governance. Stanford, CA: Rock Center for Corporate Governance.

Lehohla, P. 2013. Mid-year population estimates: 2013. Pretoria: Statistics South Africa.

Lehohla, P. 2014. Quarterly Employment Statistics: March 2014. Pretoria: Statistics South Africa.

Lippert, RL \& Porter, G. 1997. Understanding CEO pay: A test of two pay-toperformance sensitivity measures with alternative measures of alignment and influence. Journal of Business Research 40(2):127-138.

McDonald, ML \& Westphal, JD. 2013. Access denied: Low mentoring of women and minority first-time directors and its negative effects on appointments to additional boards. Academy of Management Journal 56(4):1169-1198.

Merton, RK. 1968. The Matthew effect in science. Science 159(38):56-63. 
Miller, T \& del Carmen Triana, M. 2009. Demographic diversity in the boardroom: Mediators of the board diversity-firm performance relationship. Journal of Management Studies 46(5):755-786.

Mobbs, S. 2013. CEOs under fire: The effects of competition from inside directors on forced CEO turnover and CEO compensation. Journal of Financial and Quantitative Analysis 48(03):669-698.

Nel, M. 2012. Sensitivity of guaranteed cost to company of CEOs in the South African retail and consumer good sector. University of Pretoria, Illovo: Gordon Institute of Business Science.

Nzukuma, KC \& Bussin, M. 2011. Job-hopping amongst African Black senior management in South Africa: original research. SA Journal of Human Resource Management 9(1):1-12.

Ozkan, N. 2011. CEO compensation and firm performance: An empirical investigation of UK panel data. European Financial Management 17(2):260-285.

Pallant, J. 2010. SPSS survival manual: A step by step guide to data analysis using SPSS. Maidenhead: McGraw-Hill International.

Park, SH \& Westphal, JD. 2013. Social discrimination in the corporate elite: How status affects the propensity for minority CEOs to receive blame for low firm performance. Administrative Science Quarterly 58(4):542-586.

Richard, OC, Murthi, B \& Ismail, K. 2007. The impact of racial diversity on intermediate and long-term performance: The moderating role of environmental context. Strategic Management Journal 28(12):1213-1233.

Saunders, M \& Lewis, P. 2011. Doing research in business and management: An essential guide to planning your project. Financial Times. Harlow: Prentice Hall.

Scheepers, D, Spears, R, Doosje, B \& Manstead, AS. 2006. Diversity in in-group bias: Structural factors, situational features, and social functions. Journal of Personality and Social Psychology 90(6):944.

Selody, K. 2010. Board independence and the gender pay gap for top executives. Ithaca, NY: Compensation Research Initiative.

Shaw, P. 2012. CEO pay-performance sensitivity in South African financial services companies. University of Pretoria, Illovo: Gordon Institute of Business Science.

Show, K \& Zhang, M. 2010. Is CEO cash compensation punished for poor firm performance? The Accounting Review 85(3):1065-1093.

Tosi, HL, Werner, S, Katz, JP \& Gomez-Mejia, LR. 2000. How much does performance matter? A meta-analysis of CEO pay studies. Journal of Management, 26(2):301339.

Tregenna, F \& Tsela, M. 2012. Inequality in South Africa: The distribution of income, expenditure and earnings. Development Southern Africa 29(1):35-61.

Van Blerck, TG. 2012. The relationship between executive remuneration at financial institutions and economic value added. University of Pretoria, Illovo: Gordon Institute of Business Science.

Van Melle Kamp, C \& Hofmeyr, K. 2013. CEO route to the top: The South African experience. Johannesburg: Spencer Stuart \& Gordon Institute of Business Science. 
Wade, JB, Porac, JF, Pollock, TG \& Graffin, SD. 2006. The burden of celebrity: The impact of CEO certification contests on CEO pay and performance. Academy of Management Journal 49(4):643-660.

Wang, K \& Xiao, X. 2011. Controlling shareholders' tunneling and executive compensation: Evidence from China. Journal of Accounting and Public Policy 30(1): 89-100.

Weinstock, M. 2014. Celebrating diversity. Hospitals \& Health Networks/AHA 88(4):9.

Wessel, D. 2006. With CEO pay, size does matter. Wall Street Journal. Available at: http://online.wsj.com/article_print/SB116242171357310677.html (accessed on 11 February 2006).

Whitfield, B. 2013. CEO in pay-cut shock. Finweek 19 December.

Zhou, X. 2000. CEO pay, firm size, and corporate performance: Evidence from Canada. Canadian Journal of Economics/Revue canadienne d'économique 33(1): 213-251.

World Economic forum. 2015. The Global Competitiveness Report, Full Data Edition. Geneva: World Economic Forum.

Zweigenhaft, RL \& Domhoff, GW. 2011. The New CEOs: Women, African American, Latino, and Asian American Leaders of Fortune 500 Companies. Lanham, MD: Rowman \& Littlefield. 